Research Article Animal Genetics

\title{
Molecular data reveal a complex population genetic structure for Psalidodon scabripinnis (Teleostei: Characidae) in the Atlantic Rainforest, Brazil
}

\author{
Daniel Meneguello Limeira ${ }^{1}$ (D), Mateus Henrique Santos ${ }^{2}$, Rogério Pincela Mateus ${ }^{3}$ (D), Claudete de Fátima \\ Ruas $^{4}$, Mara Cristina de Almeida ${ }^{2}$, Orlando Moreira-Filho ${ }^{5}$ and Roberto Ferreira Artoni ${ }^{2}$ (1) \\ ${ }^{I}$ Instituto Federal do Paraná, Londrina, PR, Brazil. \\ ${ }^{2}$ Universidade Estadual de Ponta Grossa, Departamento de Biologia Estrutural Molecular e Genética, \\ Laboratório de Genética Evolutiva, Ponta Grossa, PR, Brazil. \\ ${ }^{3}$ Universidade Estadual do Centro-Oeste, Departamento de Ciências Biológicas, Laboratório de Genética e \\ Evolução, Guarapuava, PR, Brazil. \\ ${ }^{4}$ Universidade Estadual de Londrina, Departamento de Biologia Geral, Laboratório de Marcadores \\ Moleculares e Citogenética de Plantas, Londrina, PR, Brazil. \\ ${ }^{5}$ Universidade Federal de São Carlos, Departamento de Genética e Evolução, Laboratório de Citogenética \\ e Biodiversidade, São Carlos, SP, Brazil.
}

\begin{abstract}
Recently renamed, Psalidodon scabripinnis populations of Serra da Mantiqueira, previously known as Astyanax scabripinnis have been deeply studied in the last years. These populations are small and isolated and occur very close to the watershed between Paraíba do Sul River basin and Upper Paraná River basin, in Serra da Mantiqueira region in the Atlantic Rainforest. These conditions arouse the interest in knowing theor genetic conservation status and how they responded to the separation between the two rivers basins. Therefore, we accessed the genetic diversity of five $P$. scabripinnis populations of this region with microsatellites and mitochondrial data. The results showed a complex structure pattern that doesn't match the simple basin separation and a reasonably conservation status when compared with other populations of the same family or with similar natural history.
\end{abstract}

Keywords: Lambaris, Campos do Jordão plateau, genetic diversity, microsatellites, mitochondrial data.

Received: February 15, 2021; Accepted: December 08, 2021.

\section{Introduction}

Serra da Mantiqueira (SM) is a mountain range formed by crystalline rocks, located at Atlantic Rainflorest in southeastern Brazil. In general, its origin is associated with tectonic movements of the lower Cretaceous plate some 70 million years before the present time (Modenesi-Gauttieri et al., 2002). However, there is evidence of more recent tectonic activities, causing the final elevation of the SM during the Quaternary, a period that started 1.8 million years ago and extends into the present (Hiruma et al., 2001). Along the SM, there are flat landscapes from ancient erosions, such as the Campos do Jordão plateau, between the states of São Paulo and Minas Gerais, and Itatiaia, in the state of Rio de Janeiro (Modenesi-Gauttieri et al., 2002).

The Campos do Jordão plateau occurs at altitudes that reach more than 2,000 meters (Almeida and Carneiro, 1998). It is limited by steep cliffs that rise approximately 1,500 meters from the Paraíba do Sul valley (Modenesi-Gauttieri and Hiruma, 2004), consisting of transient faults directed to the northwest: the Jundiuvira Fault and the Paiol Grande Fault (Hasui et al., 1978).

Send correspondence to Daniel Meneguello Limeira. Instituto Federal do Paraná, Av. da Liberdade, B1, Lote 26, Gleba Jacutinga, 86077-080, Londrina, PR, Brazil. E-mail: daniel.limeira @ifpr.edu.br.
Ingênito and Buckup (2007) investigated the potential of the SM as a biogeographic barrier for ichthyofauna between the Paraíba do Sul and Upper Paraná River basins. The authors found the coexistence of species in both basins, including one from the group Astyanax scabripinnis (Characiformes), identified is these work as Astyanax sp.1, a species now renamed Psalidodon scabripinnis by Terán et al. (2020). The authors concluded that the SM acts as an efficient barrier between the faunas of both basins. However, the work did not have a population approach and variations at this level are still open to question.

The ichthyofauna of the Paraíba do Sul River has also been characterized and studied by other authors who identified endemic regions, species introduction, and some possible headwater capture points in the basin (Bizerril, 1998).

The Astyanax scabripinnis complex (Moreira-Filho and Bertollo, 1991), or Psalidodon scabripinnis as we will call it here, is particularly interesting because it forms isolated populations at the headwaters of streams that present great karyotype variation, wide geographical distribution, from Espírito Santo to Rio Grande do Sul (reviewed in MoreiraFilho et al., 2004).

Although studies are being performed in this species with chromosomal markers approximately for more than four decades, the populations of $P$. scabripinnis from the Serra da Mantiqueira have never been studied with molecular markers 
of diversity. Thus, our objective in this work was to access the genetic diversity of these populations with molecular markers, to test hypotheses of structuring and genetic conservation.

\section{Material and Methods}

\section{Collection area}

We collected 148 specimens of Psalidodon scabripinnis from five different collection sites (Figure 1), each one of a different stream, three belonging to the Paraíba do Sul River basin (Córrego Lavrinhas, Ribeirão Grande, and Ribeirão Pequeno) and the other two belonging to the Sapucaí River basin, a tributary of Rio Grande, which in turn is a tributary of the Upper Paraná River (Córrego das Pedras and Ribeirão Perdizes). All the sampling sites belongs to the Serra da Mantiqueira region and are next or in the Campos do Jordão plateau.

Due to taxonomic uncertainties concerning the group, a sample of five individuals from each collection point was selected for molecular identification (barcode) using the cytochrome c oxidase I (COI) gene. In addition, we sent another sample from each point for confirmation to the Museum of Zoology at the State University of Londrina. The locations, codes assigned to the populations, sample number, municipalities, and geographic coordinates of the collection points are presented in Table 1. The same table also shows the number of the voucher generated by the deposit of some of the copies in ichthyology/zoology museums for the five populations. The small number of individuals collected in the Ribeirão Pequeno population made a deposit impossible.

\section{Microsatellites}

The total DNA was extracted using the CTAB method (Cetyltrimethylammonium bromide) (Boyce et al., 1989). We selected six polymorphic microsatellite loci (Table S1) described by Zaganini et al. (2012) to Psalidodon ( Astyanax) altiparanae (Characiformes), whose transferability has already been tested to P. scabripinnis (Limeira et al., 2019). The

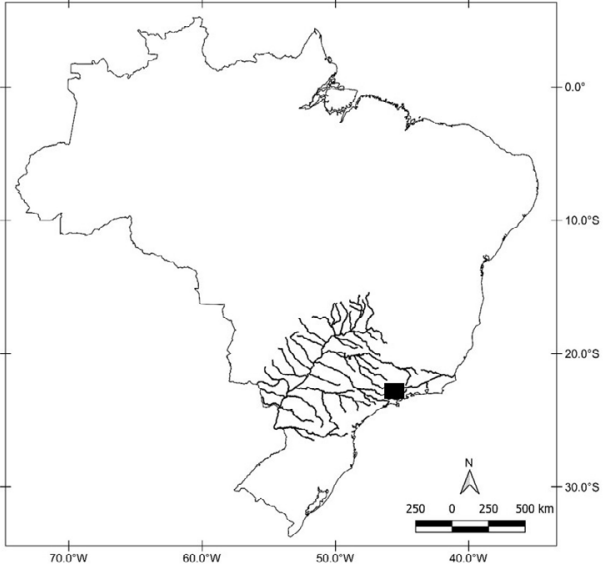

Legend:

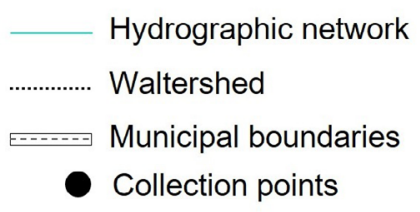

Hypsometric

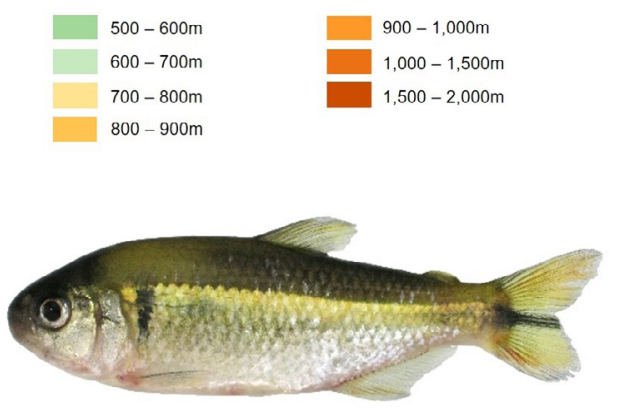

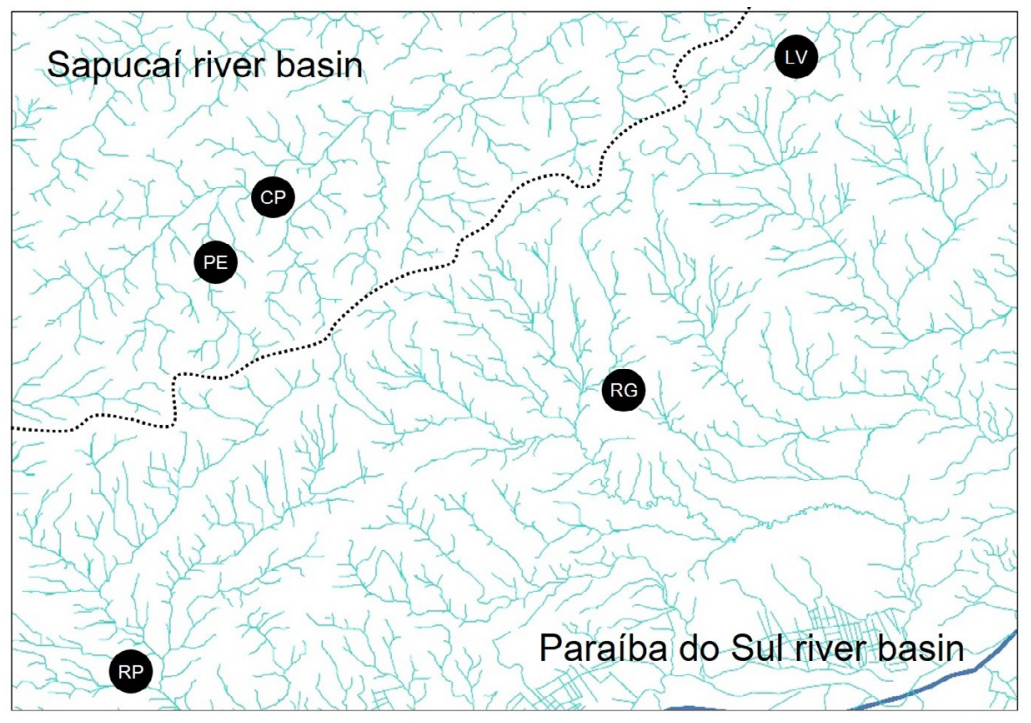

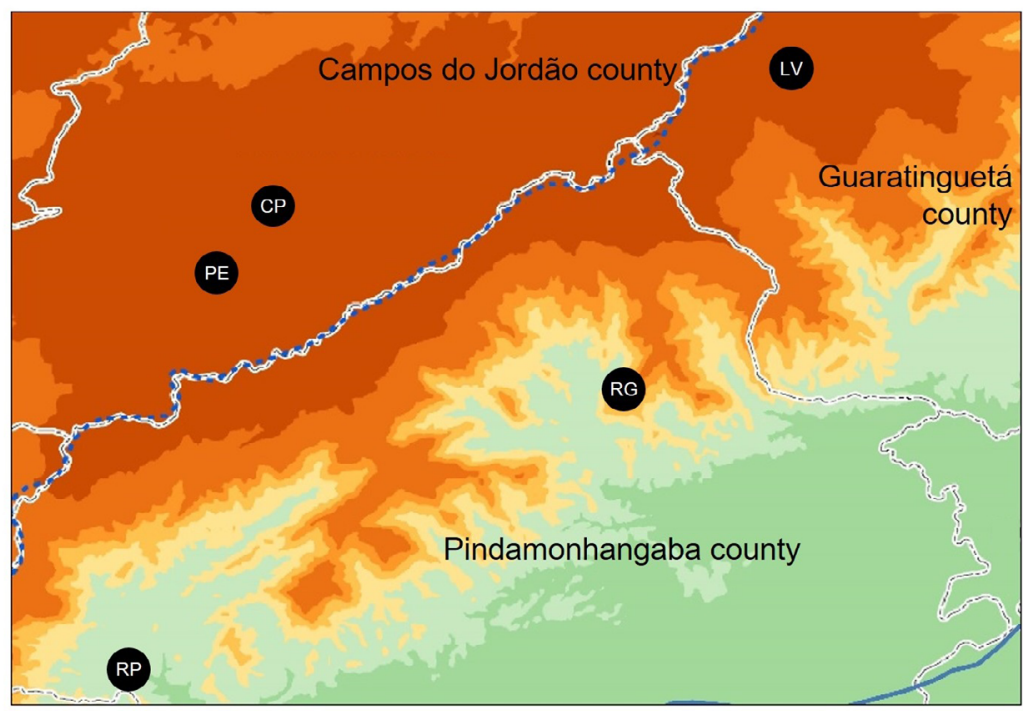

Figure 1 - Collection sites for the examples of Psalidodon scabripinnis. Above and to the left, the Paraná River and Paraíba do Sul River basins; the black dot represents the collection area. Below and to the left, a specimen of Psalidodon scabripinnis. Above and to the right, approximation to the collection points and the hydrographic network; below and to the right, approximation of the collection sites, showing the altitude of each site. 
amplifications were made using the GoTaq ${ }^{\mathrm{TM}}$ Green Master Mix Kit from Promega, with forward primers plus M13 tail and with the universal primer M13 (Schuelke, 2000) marked with FAM, HEX, and NED. PCRs were performed in a final volume of $10 \mu \mathrm{l}$ composed of $4.5 \mu 1$ of the Master Mix Kit, $0.32 \mu 1$ of the reverse primers and M13 (final concentration in the reaction of $0.32 \mathrm{pmol} / \mu \mathrm{l}), 0.08 \mu \mathrm{l}$ of the forward primer (final concentration in the reaction of $0.08 \mathrm{pmol} / \mu \mathrm{l}$ ) plus the M13 tail, $2 \mu 1$ of the DNA sample (20 ng in the final reaction) and $2.78 \mu \mathrm{l}$ of ultrapure water. The amplification cycles started with a five-minute denaturation stage at $95{ }^{\circ} \mathrm{C}$, followed by 35 cycles of $30 \mathrm{~s}$ at $95{ }^{\circ} \mathrm{C}$ for denaturation, $30 \mathrm{~s}$ of annealing, where the temperature depended on the primers, and $30 \mathrm{~s}$ of extension at $72^{\circ} \mathrm{C}$. At the end of the 35 cycles, eight more followed to mark the fragments, composed of an initial denaturation stage of $95{ }^{\circ} \mathrm{C}$, annealing at $53{ }^{\circ} \mathrm{C}$ and extension at $72{ }^{\circ} \mathrm{C}$, all for $30 \mathrm{~s}$. Finally, an extension stage of $72{ }^{\circ} \mathrm{C}$ was completed for $5 \mathrm{~min}$.

Genotyping was performed in an ABI $3500 \mathrm{XL}$ sequencer (Applied Biosystems), using the GeneScan 600 LIZ $^{\text {TM }}$ (ThermoFisher Scientific) as the size standard and the electropherograms were interpreted using the program GELQUEST (Sequentix - Digital DNA Processing - Klein Raden, Germany), with the alleles being named for their size. Subsequently, the software TANDEM (Matschiner and Salzburger, 2009) was used for the final adjustment of the alleles.

We investigated genotyping problems, such as the existence of null alleles, stuttering, and allelic dropouts using MICRO-CHECKER 2.2.3 (Van Oosterhout et al., 2004). As the presence of null alleles was detected in several loci, the genotypes were adjusted using the same program. All the following analyses were conducted with the adjusted genotype matrix and with the genotype matrix without the MICROCHECKER adjustment and there were no significant changes in the results (data not shown). In this way, we produced the data presented here with the adjusted genotypes, with exception of $\mathrm{F}_{\mathrm{ST}}$ values. Subsequently, to investigate the presence of linked loci, we tested the Linkage disequilibrium in two programs that showed similar results: ARLEQUIN 3.5.2 (Excoffier and Lischer, 2010) and GENEPOP 1.2-on line (Raymond and Rousset, 1995) and corrected with the Bonferroni Sequential Adjustment (Rice, 1989). Both tests were conducted with 10,000 dememorizations, 1,000 batches, and 10,000 interactions per batch.
To correct the $\mathrm{F}_{\mathrm{ST}}$, we used FREENA program, with the ENA method (excluding null alleles, Chapuis and Estoup, 2007). This method corrects the positive bias induced by the presence of null alleles and corrects the $\mathrm{F}_{\mathrm{ST}}$ values.

For the six loci used, the mean number of alleles per locus $\left(\mathrm{N}_{\mathrm{A}}\right)$, the effective number of alleles $\left(\mathrm{N}_{\mathrm{E}}\right)$, the number of private alleles $\left(\mathrm{N}_{\mathrm{AP}}\right)$, the levels of observed and expected heterozygosity $\left(\mathrm{H}_{\mathrm{O}}\right.$ and $\mathrm{H}_{\mathrm{E}}$, respectively), and the gene fixation indices for each population were calculated using GENALEX 6.501 (Peakall and Smouse, 2012). Allelic richness $\left(A_{R}\right)$ was calculated using the HP-Rare program (Kalinowski, 2005), using the rarefaction factor equal to 20 , which is the largest number of alleles found in a single locus. This program works using the rarefaction model developed by Hurlbert (1971), correcting sampling errors, since collections did not always result in the same number of individuals.

The investigation of loci outside the Hardy-Weinberg Equilibrium was carried out using the exact tests of GENEPOP 1.2-on line (Raymond and Rousset, 1995) and ARLEQUIN 3.5.2 (Excoffier and Lischer, 2010), with 10,000 dememorizations, 1,000 batches, and 10,000 interactions per batch, as parameters for Markov chains. Both programs are based on the algorithm developed by Guo and Thompson (1992), suitable for studying populations with microsatellites that present several alleles per locus.

The patterns of population structure were investigated using STRUCTURE 2.3.4 (Pritchard et al. 2000), considering the model of admixture ancestry with allelic frequencies correlated between populations. The best $\mathrm{K}$ value (number of populations or clusters) was determined by testing $\mathrm{K}$ values from 1 to 7 , with 20 replicates each. The burn-in period was 10,000 with a number of Monte Carlo simulations via Markov chains of 100,000 after the burn-in. The K value that best explains the structuring of populations was determined according to Evanno et al. (2005), using the on line tool Structure Harvester (Earl and Vonholdt, 2012). To deepen the investigation on the structuring, we conducted an analysis in STRUCTURE following the method proposed by Coulon et al. (2008). By this approach, initially the number of genetic groups was determined (best $\mathrm{K}$ value). After determination of this value, we separated the populations, according to the groups obtained and carried out new tests in each group, following the same parameters. Thus, we repeated these procedures until each test resulted in the least inclusive levels

Table 1 - Locations, population codes, municipalities, geographic coordinates of collection points, and voucher numbers (tumble number) of ichthyology/ zoology museums.

\begin{tabular}{|c|c|c|c|c|c|}
\hline Location/Population code & Municipalities & $\mathrm{N}$ & Geographic coordinates & Elevation & Voucher number \\
\hline Córrego das Pedras / CP & Campos do Jordão/SP & 36 & $22^{\circ} 43^{\prime} 33.2^{\prime \prime} \mathrm{S} 45^{\circ} 33^{\prime} 7.40^{\prime \prime} \mathrm{W}$ & $1619 \mathrm{~m}$ & MZUEL 5655 \\
\hline Córrego Perdizes / PE & Campos do Jordão/SP & 30 & $22^{\circ} 44^{\prime} 35.3^{\prime \prime} \mathrm{S} 45^{\circ} 34^{\prime} 11.6^{\prime \prime} \mathrm{W}$ & $1638 \mathrm{~m}$ & NUP 17484 \\
\hline Lago Capivari / LC & Campos do Jordão/SP & 30 & $22^{\circ} 43^{\prime} 02.8^{\prime \prime} \mathrm{S} 45^{\circ} 33^{\prime} 51.9^{\prime \prime} \mathrm{W}$ & $1558 \mathrm{~m}$ & NUP 17486 \\
\hline Ribeirão Grande / RG & Pindamonhangaba/SP & 21 & $22^{\circ} 46^{\prime} 57.38^{\prime \prime} \mathrm{S} 45^{\circ} 26^{\prime} 33.80^{\prime \prime} \mathrm{W}$ & $921 \mathrm{~m}$ & MZUEL 5656 \\
\hline Córrego Lavrinhas / LV & Guaratinguetá/SP & 35 & $22^{\circ} 40^{\prime} 46.8^{\prime \prime} \mathrm{S} 45^{\circ} 23^{\prime} 33.2^{\prime \prime} \mathrm{W}$ & $1863 \mathrm{~m}$ & NUP 17482 \\
\hline Ribeirão Pequeno / RP & Pindamonhangaba /SP & 26 & $22^{\circ} 52^{\prime} 13.75^{\prime \prime} \mathrm{S} 45^{\circ} 35^{\prime} 43.51^{\prime \prime} \mathrm{W}$ & $606 \mathrm{~m}$ & \\
\hline
\end{tabular}

MZUEL: Zoology Museum of the State University of Londrina; NUP: Ichthyological Collection of the Limnology, Ichthyology and Aquaculture Research Group (Nupelia) of the State University of Maringá. 
possible, that is, until the analyses did not demonstrate the hierarchization in genetic groups, superior to the populations.

The analysis of molecular variance (AMOVA) was performed in ARLEQUIN 3.5.2 (Excoffier and Lischer, 2010), with 10,000 permutations, assuming two patterns of hierarchization. We supposed initially that the hierarchization pattern follows the logic of separating both populations in two hydrographic basins: populations of water bodies that drain into the Sapucaí River basin and populations of water bodies that drain into the Paraíba do Sul River basin. In the second, we hierarchized the data assuming the formation of three groups. The first formed by the PE, RG, and LV populations, the second group formed only by the $\mathrm{CP}$ population, and the third by the RP population. This hierarchization hypothesis was extracted from the results of the STRUCTURE Bayesian analysis.

We investigated gene flow patterns and calculated the Effective Population Size (Ne) for each population using MIGRATE 3.6.11 (Beerli and Felsenstein, 2001; Beerli, 2006). This program is able to estimate both parameters using Bayesian inference and the principle of maximum likelihood. MIGRATE calculates two population parameters scaled by the mutation rate: the migration rate, expressed by $\mathrm{M}$, and the effective population size, expressed by Ne. The rate of migration escalated by the rate of mutation, then, depends on two factors. The first, $m$, is the migration rate, which is the fraction of individuals in a population made up of immigrants or the probability that a randomly chosen individual is an immigrant and the second is, of course, the mutation rate $(\mu)$. Thus, $\mathrm{M}_{\mathrm{i} \rightarrow \mathrm{j}}=m_{\mathrm{i} \rightarrow \mathrm{j}} / \mu$ represents the rate of immigrants, within the effective population size, in the population $j$ coming from the population $i$. The value of the mutation rate used here was $5.56 \times 10^{-4}$ (Yue et al., 2007; Bradic et al., 2012).

To try to identify the gene flow patterns, a chain with 500,000 steps without replicates was used, being sampled every 100 steps, the first 10,000 steps being discarded (burn-in period), and single-step mutations model as parameters for the Bayesian inference. For these analyses, we used three strategies: (a) investigation of the gene flow only among the populations in the Sapucaí basin; (b) investigation of gene flow only among populations in the Paraíba do Sul basin; and (c) investigation of gene flow between the Sapucaí basin and between the Paraíba do Sul basin. In all analyses, the geographical distances between the collection points were used.

\section{Mitochondrial data}

To obtain markers based on COI and ATPase 6/8 sequences, we used five individuals from each population, always with forward and reverse sequences. For COI, the amplifications occurred using the primers FishF1 (5'-TCAACCAACCACAAAGACATTGGCAC-3') and FishR1 (5'-TAGACTTCTGGG TGGCCAAAGAATCA-3') (Ward et al., 2005). The amplification reactions were carried out in solutions containing $2.5 \mathrm{mM} \mathrm{MgCl}_{2}, 0.2 \mathrm{mM}$ dNTPs, $0.2 \mu \mathrm{M}$ of each primer (Forward and Reverse), and 0.2 unit of Taq DNA Polymerase and $25 \mathrm{ng}$ of DNA from each individual, supplemented with $2.5 \mu 1$ of enzyme buffer (10X) and ultrapure water for a final volume of $25 \mu \mathrm{l}$. The amplification cycles occurred with an initial denaturation of $95^{\circ} \mathrm{C}$ for two minutes, followed by 35 cycles of $30 \mathrm{~s}$ at $94{ }^{\circ} \mathrm{C}$ for denaturation,
$30 \mathrm{~s}$ at $54{ }^{\circ} \mathrm{C}$ for the annealing of primers and one minute at $72{ }^{\circ} \mathrm{C}$ for extension. After the cycles, a final extension was performed of $72{ }^{\circ} \mathrm{C}$ for $5 \mathrm{~min}$. For ATPase 6/8), the primers L8331 (5'-AAGCRTYRGCCTTTTAAGC-3') and H9236 (5'-GTTAGTGGTCAKGGGCTTGGRTC-3') (Sivasundar et al., 2001) were used. The amplification reactions were carried out under the same conditions used for COI, with the temperature of $57{ }^{\circ} \mathrm{C}$ for the annealing of primers as the only alteration.

All reaction products were applied on 1\% agarose gel to verify the quality of the amplifications. These products were then purified with the GFX ${ }^{\mathrm{TM}}$ PCR DNA and Gel Band Purification Kit (GE Healthcare) according to the manufacturer's instructions. After the purifications, the COI amplified fragments were sent for sequencing in ACTGene, linked to Ludwig Biotecnologia Ltda, located in Alvorada-RSBrazil. ATPase fragments were sent to Macrogen, Seoul-KOR.

After obtaining the sequences, we compared each individual one with deposited sequences in GenBank, to confirm similarity. Subsequently, we checked for the presence of gaps or misaligned bases in the MEGA 7.0 program (Kumar et al., 2015). In the same program, the forward and reverse sequences of each individual were manually corrected, that is, each mutation or absence of base determination was checked individually and the consensus sequences for each individual were generated. With the consensus sequences of each individual, all sequences of all individuals were aligned using MUSCLE (Edgar, 2004 - implemented in MEGA 7) and the mutation points and/or points of absence of base determination were checked again, one by one. Finally, all sequences obtained were deposited in NCBI GeneBank, with accession number SUB8903994 (COI) and MW628613 to MW628634 (ATPase).

We conducted in ARLEQUIN 3.5.2 (Excoffier and Lischer, 2010) an investigation of the genetic diversity parameters for the COI and ATPase fragments: haplotypic diversity $(h)$, and nucleotide diversity $(\pi)$ and analysis of population structure by AMOVA (Molecular Variance Analysis). Also in ARLEQUIN, we carried out selective neutrality tests D of Tajima (Tajima, 1989) and Fs of Fu (Fu and $\mathrm{Li}, 1993$ ) for both the COI and the ATPase.

\section{Results}

\section{DNA Barcoding}

The COI test using the mitochondrial cytochrome $\mathrm{c}$ oxidase I gene revealed that the genetic distance between two populations varied from 0 to $0.6 \%$, so that all the populations studied here can be treated as belonging to the same species.

\section{Microsatellites analysis}

The analysis with the MICRO-CHECKER revealed the presence of stutter only in locus 12 of the population of Córrego Lavrinhas. Allelic dropouts were not observed. Null alleles were visualized in several loci. The Linkage disequilibrium analysis, after the Bonferroni Sequential Adjustment (Rice, 1989), did not result in significant values between at least two of the loci in all populations and, therefore, no locus was removed from the analysis. 
After adjusting the genotypes, the mean number of alleles, for all loci in all populations, ranged from 4.833 to 9.833, the mean number of effective alleles ranged from 3.443 to 6.447 , and the mean allelic richness from 4.591 to 7.785 . The means of observed and expected heterozygosities, in all populations, ranged from 0.563 to 0.698 and 0.665 to 0.825 , respectively (Table 2). The population of Córrego das Pedras (CP) showed the highest values of allelic diversity parameters (number of alleles, effective number of alleles, and allelic richness), and the least allelic diversity was presented by the PE population.
The highest heterozygosity was observed in the RP population (0.698), while the lowest was observed in the LV population (0.563), while the largest heterozygote deficiency was in the RG population (0.207). Gene fixation indices $\left(\mathrm{F}_{\mathrm{IS}}\right)$ and the numerical comparison between the expected and observed heterozygosities suggest that there is no deficit of heterozygotes only in the RP population and frequent inbreeding between populations. Only five loci among the populations (about 14\%) were found outside the EHW (Table 2).

Genetic structuring via $\mathrm{F}_{\mathrm{ST}}$ demonstrated that, genetically, RP differs the most from the others, followed

Table 2 - Genetic diversity parameters of five Psalidodon scabripinnis populations in the Sapucaí and Paraíba do Sul River basins, Serra da Mantiqueira region.

\begin{tabular}{|c|c|c|c|c|c|c|c|c|c|c|c|}
\hline & Pop & Locus & $\mathrm{N}$ & $\mathrm{N}_{\mathrm{A}}$ & $\mathrm{N}_{\mathrm{E}}$ & $A_{R}$ & $\mathrm{~N}_{\mathrm{AP}}$ & $\mathrm{H}_{\mathrm{O}}$ & $\mathrm{H}_{\mathrm{E}}$ & $\mathrm{F}_{\text {IS }}$ & \\
\hline \multirow{14}{*}{ 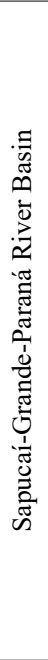 } & \multirow{6}{*}{$\mathrm{CP}$} & Asty21 & 30 & 12 & 6.977 & 7.662 & 6 & 0.733 & 0.857 & 0.144 & \multirow[t]{3}{*}{$*$} \\
\hline & & Asty23 & 33 & 11 & 4.829 & 7.268 & 2 & 0.727 & 0.793 & 0.083 & \\
\hline & & Asty26 & 26 & 5 & 4.147 & 4.290 & - & 0.769 & 0.759 & -0.014 & \\
\hline & & Asty 27 & 15 & 7 & 5.488 & 5.707 & 2 & 0.600 & 0.818 & 0.266 & * \\
\hline & & Asty12 & 16 & 7 & 5.12 & 5.970 & 2 & 0.688 & 0.805 & 0.146 & \\
\hline & & Asty04 & 20 & 17 & 12.121 & 9.941 & 13 & 0.5 & 0.918 & 0.455 & * \\
\hline & & $\mathrm{M} / \mathcal{\Sigma}$ & & 9.833 & 6.447 & 6.806 & 25 & 0.670 & 0.825 & 0.180 & \\
\hline & \multirow{7}{*}{$\mathrm{PE}$} & Asty21 & 23 & 7 & 4.921 & 6.493 & - & 0.696 & 0.797 & 0.127 & \multirow{6}{*}{$*$} \\
\hline & & Asty23 & 30 & 4 & 2.975 & 3.557 & - & 0.767 & 0.664 & -0.155 & \\
\hline & & Asty26 & 30 & 4 & 2.507 & 3.326 & - & 0.467 & 0.601 & 0.224 & \\
\hline & & Asty27 & 11 & 4 & 3.227 & 3.333 & - & 0.545 & 0.690 & 0.210 & \\
\hline & & Asty12 & 23 & 5 & 3.752 & 4.621 & - & 0.696 & 0.733 & 0.052 & \\
\hline & & Asty04 & 13 & 5 & 3.756 & 4.824 & - & 0.615 & 0.734 & 0.161 & \\
\hline & & $\mathrm{M} / \bar{\varepsilon}$ & & 4.833 & 3.523 & 4.359 & - & 0.631 & 0.703 & 0.103 & \\
\hline \multirow{21}{*}{ 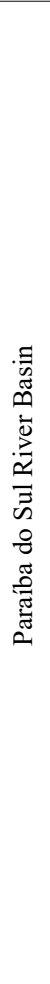 } & \multirow{7}{*}{$\mathrm{RG}$} & Asty21 & 21 & 6 & 4.594 & 5.379 & - & 0.81 & 0.782 & -0.035 & \\
\hline & & Asty 23 & 21 & 5 & 3.279 & 3.952 & - & 0.714 & 0.695 & -0.028 & \\
\hline & & Asty26 & 21 & 4 & 2.602 & 3.801 & - & 0.524 & 0.616 & 0.149 & \\
\hline & & Asty27 & 5 & 4 & 3.333 & 3.598 & 1 & 0.2 & 0.7 & 0.714 & \\
\hline & & Asty12 & 17 & 6 & 4.587 & 5.458 & - & 0.647 & 0.782 & 0.173 & \\
\hline & & Asty04 & 13 & 5 & 3.756 & 4.666 & - & 0.538 & 0.734 & 0.266 & \\
\hline & & $\mathrm{M} / \mathcal{\Sigma}$ & & 5 & 3.692 & 4.476 & 1 & 0.572 & 0.718 & 0.207 & \\
\hline & \multirow{6}{*}{ LV } & Asty21 & 26 & 9 & 6.259 & 7.128 & - & 0.692 & 0.84 & 0.176 & \\
\hline & & Asty23 & 22 & 9 & 4.99 & 6.660 & - & 0.636 & 0.8 & 0.204 & \\
\hline & & Asty26 & 35 & 3 & 1.514 & 2.822 & - & 0.286 & 0.34 & 0.159 & \\
\hline & & Asty 27 & 8 & 4 & 3.282 & 3.429 & - & 0.625 & 0.695 & 0.101 & \\
\hline & & Asty12 & 13 & 5 & 3.314 & 4.479 & - & 0.615 & 0.698 & 0.119 & \\
\hline & & Asty04 & 23 & 5 & 2.612 & 4.002 & - & 0.522 & 0.617 & 0.155 & \\
\hline & & $\mathrm{M} / \mathcal{\Sigma}$ & & 5.833 & 3.662 & 4.753 & - & 0.563 & 0.665 & 0.152 & \\
\hline & \multirow{7}{*}{$\mathrm{RP}$} & Asty21 & 19 & 5 & 3.455 & 4.459 & - & 0.632 & 0.711 & 0.111 & \\
\hline & & Asty23 & 25 & 9 & 3.858 & 6.173 & 1 & 0.84 & 0.741 & -0.134 & \\
\hline & & Asty26 & 25 & 6 & 2.358 & 4.780 & 3 & 0.52 & 0.576 & 0.097 & \\
\hline & & Asty27 & 14 & 5 & 3.469 & 4.044 & - & 0.643 & 0.712 & 0.097 & \\
\hline & & Asty12 & 17 & 9 & 5.402 & 6.608 & 3 & 0.706 & 0.815 & 0.134 & \\
\hline & & Asty04 & 26 & 3 & 2.058 & 2.385 & 1 & 0.846 & 0.514 & -0.646 & $*$ \\
\hline & & $\mathrm{M} / \boldsymbol{\varepsilon}$ & & 6.167 & 3.433 & 4.742 & 8 & 0.698 & 0.678 & -0.057 & \\
\hline
\end{tabular}

$\mathrm{N}$ : sample size of each population, $\mathrm{N}_{\mathrm{A}}$ : number of different alleles; $\mathrm{N}_{\mathrm{E}}$ : effective number of alleles; $\mathrm{A}_{\mathrm{R}}$ : allelic richness; $\mathrm{N}_{\mathrm{AP}}$ : number of private alleles; $\mathrm{H}_{\mathrm{O}}$ : observed heterozygosity; $\mathrm{H}_{\mathrm{E}}$ : expected heterozygosity; $\mathrm{F}_{\mathrm{IS}}$ : gene fixation index; *loci with significant deviations from the expected Hardy-Weinberg Equilibrium after the sequential Bonferroni adjustment, $\mathrm{M} / \mathrm{\Sigma}$ : mean (for $\mathrm{N}, \mathrm{N}_{\mathrm{A}}, \mathrm{N}_{\mathrm{E}}, \mathrm{A}_{\mathrm{R}}, \mathrm{H}_{\mathrm{O}}, \mathrm{H}_{\mathrm{E}}$, and $\mathrm{F}_{\mathrm{IS}}$ ) or sum (for $\mathrm{N}_{\mathrm{AP}}$ ) of diversity parameters. 
by $\mathrm{CP}$. The PE, RG, and LV populations have little genetic differentiation between them. The global $\mathrm{F}_{\mathrm{ST}}$ value was 0.098 , the $\mathrm{F}_{\mathrm{ST}}$ values pair by pair are shown in Figure $2(\mathrm{P}<0.05$ for all values). The first Bayesian analysis test of STRUCTURE
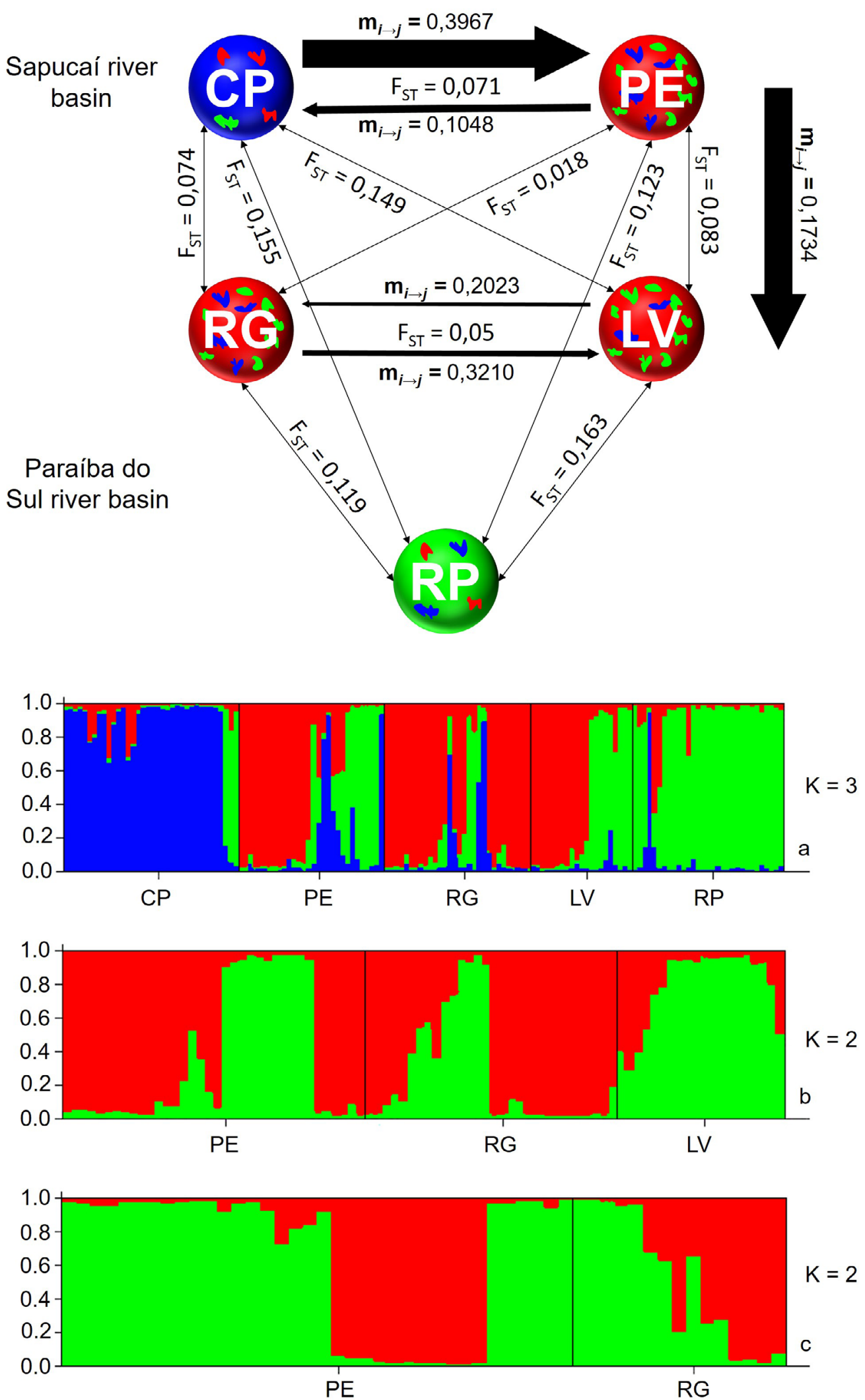

Figure 2 - Results of the genetic structuring analysis of five Psalidodon scabripinnis populations in the Sapucaí and Paraíba do Sul basins. Above, paired $\mathrm{F}_{\mathrm{ST}}$ (narrow arrows) and migration rate $\left(\mathrm{m}_{\mathrm{i} \rightarrow \mathrm{j}}\right.$, broad arrows) for the five populations. The thickness of the arrows is proportional to the migration rate. Non-significant values for the migration rate are not shown $\left(\mathrm{P}<0.05\right.$, for all values of $\left.\mathrm{F}_{\mathrm{ST}}\right)$. Below, STRUCTURE results with the three runs (a: $\mathrm{CP}+\mathrm{PE}+\mathrm{RG}+\mathrm{LV}+\mathrm{RP} ; \mathrm{b}: \mathrm{PE}+\mathrm{RG}+\mathrm{LV} ; \mathrm{c}: \mathrm{PE}+\mathrm{RG})$. 
points in the same direction, indicating three genetic groups $(\mathrm{K}=3)$, with $\mathrm{CP}$ and RP being markedly different from the other populations, while the other three populations do not demonstrate structuring among them. We noted that LV, $\mathrm{PE}$, and RG contain alleles of the same founders groups from CP and RP less frequently and of another group, not investigated here, more frequently (Figure 2a). A new test was carried out, at this new hierarchical level, with the three populations of the second group, resulting in $\mathrm{K}=2$. $\mathrm{PE}$ and $\mathrm{RG}$ are composed of both origins, whereas LV is basically composed of only one (Figure $2 \mathrm{~b}$ ). In the last run, only with the $\mathrm{PE}$ and $\mathrm{RG}$ populations and assuming $\mathrm{K}=2$, it was noted that there is no evident structure between these two populations (Figure 2c).

The gene flow analysis, through the rate of migrants investigated with MIGRATE, among populations in the Sapucaí River basin, showed that there is a greater gene flow between $\mathrm{CP}$ and $\mathrm{PE}$ populations, with the greatest direction of migration from $\mathrm{PE}$ to $\mathrm{CP}$, around four times higher. In more detail, the rate of immigrants in CP from PE is almost $40 \%$, while the rate of immigrants in the opposite direction is approximately $10 \%$ (Figure 2 ). Among the populations of the Paraíba do Sul River, strong evidence of gene flow was found between the RG and LV populations. The rate of immigrants in $\mathrm{LV}$ from $\mathrm{RG}$ is around $32 \%$, while the rate of immigrants in LV from RG is $20 \%$ (Figure 2).

The hypothesis of the formation of three groups or clusters, tested by AMOVA for both microsatellites and sequences, seems to best explain the population structure, as our data show (Table 3). This hypothesis, inferred from the results of STRUCTURE, considers a group formed by the populations $\mathrm{PE}, \mathrm{RG}$, and $\mathrm{LV}$, another only by the population $\mathrm{CP}$, and a third by the RP population. In this approach, the largest portion of the variation, for microsatellites, is found between populations $(88.82 \%)$, followed by variation between groups $(7.48 \%)$, and variation between populations within groups $(3.7 \%)$. Table 3, which also shows the values of the F-statistics $\left(\mathrm{F}_{\mathrm{ST}}, \mathrm{F}_{\mathrm{SC}}\right.$, and $\left.\mathrm{F}_{\mathrm{CT}}\right)$ and their probabilities.

Table 3 - Values of the genetic variation of three markers (Microsatellites, COI, and ATPase) obtained through AMOVA under two hypotheses of hierarchical data (Sapucaí and Paraíba do Sul Basins and groups - PE+LV+RG, CP, and RP).

\begin{tabular}{|c|c|c|c|c|c|c|}
\hline & \multicolumn{3}{|c|}{ Hierarchization of basins } & \multicolumn{3}{|c|}{ Hierarchization of groups } \\
\hline & SSRs & $\mathrm{COI}$ & ATPase & SSRs & $\mathrm{COI}$ & ATPase \\
\hline Between groups/basins & 1.49 & -7.44 & -15.84 & 7.48 & 67.59 & 65.31 \\
\hline Among populations within groups/basins & 8.529 & 53.27 & 67.00 & 3.70 & -10.03 & -1.17 \\
\hline \multirow[t]{2}{*}{ Among populations } & 89.99 & 54.17 & 48.84 & 88.82 & 42.45 & 35.86 \\
\hline & \multicolumn{3}{|c|}{ Hierarchization of basins } & \multicolumn{3}{|c|}{ Hierarchization of groups } \\
\hline $\mathrm{F}_{\mathrm{CT}}$ & 0.01490 & -0.07441 & -0.15835 & 0.07478 & 0.67585 & 0.65315 \\
\hline $\mathrm{F}_{\mathrm{SC}}$ & $0.08649 *$ & $0.49583^{*}$ & $0.57839 *$ & 0.04005 & -0.30952 & -0.03383 \\
\hline $\mathrm{F}_{\mathrm{ST}}$ & $0.10010^{*}$ & $0.45831 *$ & $0.51162 *$ & $0.11183^{*}$ & $0.57552 *$ & $0.64141^{*}$ \\
\hline
\end{tabular}

The investigation of bottlenecks, assuming the twophased mutation model (TPM), according to the Wilcoxon test $\left(\mathrm{P}_{\mathrm{WT}}\right)$, the most robust when there are less than 20 microsatellite loci, revealed a significant heterozygosity excess, suggesting a recent bottleneck only for the PE and RG populations (significance level of $\mathrm{P}<0.05$ ). The probability values can be seen in Table 4, along with the effective population sizes $(\mathrm{Ne})$, calculated using the Bayesian inference.

\section{Mitochondrial DNA analysis}

The amplification of the cytochrome c oxidase I (COI) gene resulted in fragments of, on average, $652 \mathrm{bp}$, whereas the amplifications for the ATPase gene, resulted in fragments of, on average, $884 \mathrm{bp}$, after the alignment and editing of the sequences.

The values of haplotypic and nucleotide diversity for the ATPase gene ranged from 0 to 0.8333 and from 0 to 0.0073 , respectively. As for the COI values, they ranged from 0 to 0.4 and from 0 to 0.37 , respectively. No significant values were obtained for the majority of neutrality tests (D for Tajima and Fs for $\mathrm{Fu}$ ). The results of the neutrality tests, as well as the diversity values, are shown in Table 5.
The results of the AMOVA for the mitochondrial markers (Table 3), showed that the largest part of the variation was found between the groups $(67.59 \%$ for COI and $65.31 \%$ for ATPase), followed by variation between populations $(42.45 \%$ for COI and $35.86 \%$ for ATPase), and variation between populations within groups $(-10.03 \%$ for COI and $-1.17 \%$ for ATPase).

Table 4 - Effective population sizes ( $\mathrm{Ne}$ ) provided by the MIGRATE program and probabilities of the Wilcoxon test $\left(\mathrm{P}_{\mathrm{WT}}\right)$, according to the two-phased mutation model (TPM), to test the heterozygosity excess, provided by the BOTTLENECK program, for five populations of Psalidodon scabripinnis from the Serra da Mantiqueira region.

\begin{tabular}{cccc}
\hline & Effective population size & & Heterozygosity Excess \\
\cline { 1 - 1 } Pop & $\mathrm{Ne}$ & & $\mathrm{P}_{\mathrm{WT}}(\mathrm{TPM})$ \\
\hline CP & 33.7 & & 0.578125 \\
PE & 10.7 & 0.007813 \\
RG & 16.9 & 0.007813 \\
LV & 33.5 & 0.921875 \\
RP & 2.9 & 0.921875 \\
\hline
\end{tabular}


Table 5 - Values of genetic diversity and selective neutrality test of ATPase and COI for five populations of Psalidodon scabripinnis from the Serra da Mantiqueira region.

\begin{tabular}{|c|c|c|c|c|c|c|c|c|c|c|}
\hline \multirow[b]{2}{*}{ Pop } & \multicolumn{5}{|c|}{ ATPase } & \multicolumn{5}{|c|}{ COI } \\
\hline & $N$ & $h$ & $\pi$ & $D$ & Fs & $N$ & $h$ & $\pi$ & $D$ & $F s$ \\
\hline $\mathrm{CP}$ & 4 & 0 & 0 & 0 & 0 & 4 & 0 & 0 & 0 & 0 \\
\hline $\mathrm{PE}$ & 5 & $\begin{array}{c}0.6 \\
0.1753\end{array}$ & $\begin{array}{l}0.0007 \\
0.0007\end{array}$ & 1.2247 & 0.6262 & 5 & 0 & 0 & 0 & 0 \\
\hline LV & 4 & 0 & 0 & 0 & 0 & 3 & 0 & 0 & 0 & 0 \\
\hline $\mathrm{RP}$ & 4 & $\begin{array}{l}0.8333 \\
0.2224\end{array}$ & $\begin{array}{l}0.0046 \\
0.0035\end{array}$ & -0.4464 & 1.2253 & 3 & $\begin{array}{c}0.4 \\
0.2373\end{array}$ & $\begin{array}{l}0.0037 \\
0.0029\end{array}$ & -1.1455 & 3.0225 \\
\hline RG & 5 & $\begin{array}{c}0.8 \\
0.1640\end{array}$ & $\begin{array}{l}0.0013 \\
0.0012\end{array}$ & 0.2431 & -0.4754 & 5 & 0 & 0 & 0 & 0 \\
\hline
\end{tabular}

$\mathrm{N}$ : sample size; $h$ : haplotypic diversity above and below, in the same cell the standard deviation; $\pi$ : nucleotide diversity above and below, in the same cell the standard deviation; $D$ : value of the D test of Tajima; Fs: value of the Fs test of Fu.

\section{Discussion}

Although the Serra da Mantiqueira has proven to be an efficient barrier to ichthyofauna (Ingenito and Buckup, 2007), our data demonstrated that the structuring of $P$. scabripinnis populations on the Campos do Jordão plateau does not follow the division of the basins. Thus, the simple hypothesis of the hierarchy of the populations of $P$. scabripinnis in the Serra da Mantiqueira in two groups equivalent to the basins of Sapucaí-Grande-Alto Paraná and Paraíba do Sul, does not seem to explain the genetic variation between them. This is indicated by the results of the Bayesian inference for the investigation of population structure, carried out by the STRUCTURE program. The methodology suggested by Coulon et al. (2008) was effective in showing the structure of populations, clarifying the differences between them. Note that the RP and CP populations are more genetically distant from the group formed by $\mathrm{PE}+\mathrm{RG}+\mathrm{LV}$, making it necessary to formulate an alternative hypothesis to explain the genetic variation of these populations.

Similarly, the hypothesis of hierarchization in two groups formed by the two basins, tested by AMOVA, both for microsatellite markers and for mitochondrial DNA, was not able to satisfactorily explain the variation. The variation can be better explained by hierarchizing the data into groups (RP, CP, and PE+RG+LV), as suggested by the Bayesian analysis of Structure. The analysis of the AMOVA results of both markers (Table 3) also suggests that the structuring of the populations is recent, since only the microsatellites demonstrated clear structuring.

The values and $\mathrm{F}_{\mathrm{ST}}$ point in the same direction as the AMOVA and Bayesian inference of STRUTURE. Values above the global mean $\left(\mathrm{F}_{\mathrm{ST}}=0.098\right)$ are found between $\mathrm{RP}$ and any other of the four populations and between $\mathrm{CP}$ and $\mathrm{LV}$, populations from the same basin (Figure 2). The lowest value occurs between RG and PE, populations found in different basins. Even disregarding the hierarchy, the $\mathrm{F}_{\mathrm{ST}}$ values also demonstrated a marked differentiation between populations. In order to compare these differences, we can mention studies with Astyanax mexicanus, where the highest $\mathrm{F}_{\mathrm{ST}}$ value between two populations was 0.51 and the lowest 0.01 (Bradic et al., 2012).
The use of AMOVA has been shown to be efficient for low migratory fish. Bradic et al. (2012) tested several hypotheses of population structure for $A$. mexicanus, inferred from the allelic diversity and the STRUCTURE data. The hypothesis that best explained the hierarchy of the data did not group the populations simply into cave or surface areas, demonstrating great biogeographic complexity, a scenario similar to that found in the current work. In populations with greater geographic separation and barriers more difficult to cross, the structuring hypotheses can be inferred directly from biogeographic data. For example, populations of the killifish Aphanius fasciatus collected in Greece and Turkey and separated by the Aegean Sea, presented genetic structure compatible with the geographic distribution (Triantafyllidis et al., 2007).

In fact, there is ample evidence of recent tectonic events in the region known as the Campos do Jordão Plateau. Hiruma et al. (2001) reported several headwaters capture events that occurred recently (about 10,000 years ago) in the Campos do Jordão plateau region. Modenesi-Gauttieri et al. (2002) identified drainage captures at the headwaters of Ribeirão do Sino and Córrego Lavrinhas, also found evidence of capture at several other drainages in the Campos do Jordão plateau. Evidence of recent tectonism, as well as drainage captures, reinforces the hypothesis that vicariance events among the sampled populations did not occur simultaneously and may have preceded headwaters captures.

The migration rates identified by MIGRATE help us to understand this scenario. There is strong evidence of gene flow from PE to CP while reverse flow is unlikely. These findings are reinforced by the reasonable number of loci outside the Hardy-Weinberg equilibrium observed in CP. In the Paraíba do Sul basin, there is great evidence of gene flow from RG to LV and moderate to the inverse. The RP population presented the greatest geographical distance from other populations, being 606 meters in height, with an elevation of approximately 1,000 meters less than the other populations. It is possible that, during the uplift of the crystalline edges, it was the first to separate itself from the other populations, remaining isolated for a longer time (Ingenito and Buckup, 2007) 
The comparison between geographic distances and the $\mathrm{F}_{\mathrm{ST}}$ reinforces the explanation above. Within the same basin, the highest values of $\mathrm{F}_{\mathrm{ST}}$ paired between $\mathrm{RP}$ and another population also correspond to the greatest geographical distances.

After RP, CP is the most genetically different population from the rest. Among the populations of the Sapucaí basin, CP is the furthest from the watershed and the one with the lowest altitude. As with RP, it is likely that this population has been isolated longer than PE from the populations of the Sapucaí basin. Although there are signs of gene flow from PE to CP, with weak signs to the contrary, there is a distinct difference between them. The flow from PE to CP can be explained by the geographical proximity between them. In addition, the higher PE altitude in relation to RP may contribute to the migration patterns seen.

Following this reasoning, the same applies to LV, which is also more distant from the populations of the Sapucaí basin and, among those in the Paraíba do Sul basin, is the one that lives at the highest altitude. These values indicate that LV may have been the second to separate from other populations and, due to the proximity to RG, still maintains migrations. However, the difference in altitude between RG and LV makes it difficult to explain the migration patterns indicated by MIGRATE, since there was more evidence of migration from RG to LV than to the contrary. The fact that LV does not have private alleles corroborates this observation. As RG is at $921 \mathrm{~m}$ in relation to $\mathrm{LV}$ at 1863 meters of altitude, it is not parsimonious to assume that there is easier migration from the lowest to the highest location than the other way around. However, many other factors, in addition to the altitude, that were not the subject of this study, can influence migration patterns (Fausch et al., 2002). According to Jonsson and Jonsson (1993), individuals from the same population exhibit different migratory behaviors, for example, migrants and residents may have different rates of growth and fertility. Bradic et al. (2012) showed, in Astyanax mexicanus, that cave populations receive more alleles from surface populations than they donate. The incursions of fish from the surface to the caves can occur for several reasons, including the rain regime. However, the authors also noted that some cave populations migrate more than others. Migration patterns may be contributing to the maintenance of genetic variation among populations in the region.

The populations of $P$. scabripinnis from the Serra da Mantiqueira had not yet been studied at the molecular level. Similarly, little was known about their genetic conservation status. Studies that accessed the genetic variability of Psalidodon ( Astyanax) populations with microsatellite data are extremely rare, despite of the large number of studies with with chromosomal markers (Souza and Moreira-Filho, 1995; Néo et al., 2000; Moreira-Filho et al., 2004; Castro et al., 2014). As an example, we find the populations of Astyanax mexicanus, which inhabit surface waters and caves, forming small groups with low gene flow (Protas et al., 2006), having, therefore, a natural history similar to the populations of P. scabripinnis. Panaram and Browsky (2005) analyzed populations of $A$. mexicanus with data from microsatellites and observed that the heterozygosity of populations that they classified as small ranged from 0 to 0.254 , while in large populations it ranged from 0.139 to 0.656 . Other studies with the same species revealed populations with enormous variation in the levels of heterozygosity observed: 0 to 0.905 (Strecker et al., 2003; Bradic et al., 2012). Zaganini et al. (2012) obtained for Psalidodon ( Astyanax) altiparanae in the Upper Paraná River basin high levels of heterozygosity ranging from 0.5 to 0.852 , and high levels of gene fixation in almost all loci.

When comparing the values of observed heterozygosity of the populations of $P$. scabripinnis studied here, ranging from 0.563 to 0.698 , with the studies mentioned above, it is noted that they are relatively high and less variable than the heterozygosities of populations of $A$. mexicanus. It is interesting to note here that the majority of the populations in the studies cited and our results showed a deficit of heterozygotes (Table 2).

The mean number of alleles obtained here varied from 4.8 to 9.8 , while in other Psalidodon ( $\sim$ Astyanax) the numbers varied from 2.23 to 15 , as in A. mexicanus (Strecker et al., 2003; Bradic et al., 2012). For a population of $P$. altiparanae, the mean was 7.5 (Zaganini et al., 2012). Although some of the works with Astyanax mention the number of alleles, but not allelic richness, the latter is a more informative parameter for comparing the diversity between populations, since it applies a rarefaction factor (revised by Foulley and Ollivier, 2006). This comparison demonstrates the values obtained herein (4.359 to 6.806) are within the variation found for the genus Psalidodon or Astyanax. An example of this is seen for the variation between the allelic richness means from 1.21 to 5.21 in A. mexicanus (Panaram and Borowski, 2005; Bradic et al., 2012).

The lack of studies with population-based approaches on the Psalidodon genus ( $\sim$ Astyanax $)$, makes comparisons difficult, and restricts the power of broader inferences. However, there is a greater variation in several parameters of $A$. mexicanus, such as levels of heterozygosity and allelic richness. This may be due to the large number of existing and studied populations of this species, which enabled description of the colonization of caves from various origins and in several different times (Bradic et al., 2012). This complex biogeographic scenario tends to overestimate the variation in the parameters of genetic diversity, to the detriment of the populations analyzed here, which are more restricted. However, the genetic variation of $A$. mexicanus is expected, since Central America is considered the center of origin of Astyanax (Ornelas-Garcia, 2011).

Among the populations studied herein, only RP does not present a deficit of heterozygotes $\left(\mathrm{F}_{\mathrm{IS}}=-0.057\right)$. The subdivision of populations can lead to an increase in inbreeding, which would, consequently, increase homozygosity and reduce heterozygosity. Reductions in effective population size are often linked to population genetic bottlenecks. In this scenario, genetic diversity tends to decrease, leading to an increase in inbreeding and decreasing the viability of populations (Spencer et al., 2000). According to Cornuet and Luikart (1996), during the bottleneck, allelic diversity, measured through the allelic richness and number of alleles, is initially affected due to the loss of alleles, causing the so-called allelic deficiency. Thus, the observed allelic diversity is less than the expected diversity 
in relation to the observed heterozygosity, a phenomenon known as heterozygosity excess. The heterozygosity excess is identified according to Nei (1987), while the excess of heterozygotes is calculated according to the Hardy-Weinberg Equilibrium (Cornuet and Luikart, 1996). The BOTTLENECK program showed evidence of heterozygosity excess for the $\mathrm{PE}$ and $\mathrm{RG}$ populations $(\mathrm{P}<0.05)$. These also presented small effective population sizes (10.7 and 16.9 , respectively, the two smallest among the five populations, disregarding RP) and the two smallest allelic diversity values.

Comparing PE and RG with the other populations of P. scabripinnis in this work and with the similar populations mentioned above, it can be noted that they have low levels of allelic diversity (number of alleles, effective number of alleles, and allelic richness) and indications of inbreeding $\left(\mathrm{F}_{\mathrm{IS}}\right.$ $=0.103$ and 0.207 , respectively). Similarly, mitochondrial DNA data indicate that these two populations have low levels of both haplotypic and nucleotide diversity for the COI gene and moderate for ATPase. The set of these factors, together with the small effective population size $(\mathrm{Ne})$, are indications that both populations went through bottlenecks. According to Cornuet and Luikart (1996), when a population enters a genetic bottleneck, caused by the reduction in the effective population size, inbreeding leads, initially, to the loss of allelic diversity. What is expected in the next steps, is that a heterozygosity excess appears (according to Nei, 1987), that is, the observed number of alleles is less than would be expected for the observed heterozygosity. Finally, heterozygosity is expected to decrease. Thus, it can be inferred that the bottleneck events of PE and RG are recent, as they still present moderate levels of observed heterozygosity. Among the populations in the current work, others also have relatively high levels of inbreeding or low effective population sizes, respectively CP and RP, for example. However, the allelic diversity in these populations is high which is probably why they did not show signs of bottleneck.

In fish, the decrease in population sizes can be better detected in species with high commercial interest, as well as which the genetic effects of this decrease. Vera et al. (2010) studied six populations of trout (Salmo truta caspius - Salmoniforms: Salmonidae) and detected a population bottleneck for one of them. This population also presented low genetic diversity, which, according to the authors, may have been caused by overexploitation of fishing, pollution, or destruction of spawning sites. Ferreira et al. (2016) detected signs of bottleneck in five of six populations of Geophagus braziliensis studied, and the only population that did not present a bottleneck is the one in the least anthropized environment.

Our data showed that the genetic structure of $P$. scabripinnis populations in the Serra da Mantiqueira is complex and must have been influenced by different geological events in a non-simultaneous manner. Although they are small and isolated, the populations living there present good levels of genetic variation, when compared to similar populations or those with similar biology.

\section{Acknowledgements}

Sampling was carried out by teams of the Evolutionary Genetics Laboratory of the State University of Ponta Grossa and the Cytogenetics and Biodiversity Laboratory of the Federal University of São Carlos. This project was supported by $\mathrm{CNPq}$ (Conselho Nacional de Desenvolvimento Científico e Tecnológico) and Fundação Araucária (Fundação Araucária de Apoio ao Desenvolvimento Científico e Tecnológico do Estado do Paraná).

\section{Conflict of Interest}

The authors declare that there is not confict of interest concerning to this paper.

\section{Author Contributions}

DM, RFA and OMF conceived the study; DML and CFR conducted the experiments with microsatellites; DML, RFA e MHS conducted the experiments with mitochondrial data; DML, RFA, MHS, MCA and RPM analyzed the data; DML wrote the manuscript; RFA, MHS and RPM revised the manuscript; all authors read and approved the final version.

\section{References}

Almeida FFM and Carneiro CDR (1998) Origem e evolução da Serra do Mar. Rev Bras Geocienc 28:135-150.

Beerli P (2006) Comparison of Bayesian and maximum likelihood inference of population genetic parameters. Bioinformatics 22:341-345

Beerli P and Felsenstein J (2001) Maximum likelihood estimation of a migration matrix and effective population sizes in $n$ subpopulations by using a coalescent approach. Proc Natl Acad Sci U S A 98:4563-4568.

Bizerril CRSF (1998) A Ictiofauna da Bacia do Rio Paraíba do Sul. Biodiversidade e Padrões Biogeográficos. Braz Arch Biol Technol 41:67-81.

Boyce TM, Zwick ME and Aquadrot CF (1989) Mitochondrial DNA in the bark weevils: Size, structure and heteroplasmy. Genetics 123:825-836.

Bradic M, Beerli P, García-De León FJ, Esquivel-Bobadilla S and Borowsky RL (2012) Gene flow and population structure in the Mexican blind cavefish complex (Astyanax mexicanus). BMC Evol Biol 12:9.

Castro JP, Moura MO, Moreira-Filho O, Shibatta OA, Santos MH, Nogaroto V, Vicari MR, Almeida MC and Artoni RF (2014) Diversity of the Astyanax scabripinnis species complex (Teleostei: Characidae) in the Atlantic Forest, Brazil: Species limits and evolutionary inferences. Rev Fish Biol Fish 25:231244.

Chapuis MP and Estoup A (2007) Microsatellite null alleles and estimation of population differentiation. Mol Biol Evol 24:621631.

Cornuet JM and Luikart G (1996) Description and power analysis of two tests for detecting recent population bottlenecks from allele frequency data. Genetics 144:2001-2014.

Coulon A, Fitzpatrick JW, Bowman R, Stith BM, Makarewich CA, Stenzler LM and Lovette IJ (2008) Congruent population structure inferred from dispersal behavior and intensive genetic surveys of the threatened Florida scrub-jay (Aphelocoma corulescens). Mol Ecol 17:1685-1701.

Earl DA and Vonholdt BM (2012) STRUCTURE HARVESTER: A website and program for visualizing STRUCTURE output and implementing the Evanno method. Conserv Genet Resour 4:359-361

Edgar RC (2004) MUSCLE: Multiple sequence alignment with high accuracy and high throughput. Nucleic Acids Res 32:17921797. 
Excoffier L and Lischer HEL (2010) Arlequin suite ver 3.5: A new series of programs to perform population genetics analyses under Linux and Windows. Mol Ecol Resour 10:564-567.

Fausch KD, Torgersen CE, Baxter CV and Li HW (2002) Landscapes to riverscapes: bridging the gap between research and conservation of stream fishes a continuous view of the river is needed to understand how processes interacting among scales set the context for stream fishes and their habitat. Bioscience 52:483-498.

Ferreira DG, Lima SC, Frantine-Silva W, Silva JF, Apolinário-Silva C, Sofia SH, Carvalho S and Galindo BA (2016) Fine-scale genetic structure patterns in two freshwater fish species, Geophagus brasiliensis (Osteichthyes, Cichlidae) and Astyanax altiparanae (Osteichthyes, Characidae) throughout a Neotropical stream. Genet Mol Res. DOI: 10.4238/gmr15048124.

Foulley JL and Ollivier L (2006) Estimating allelic richness and its diversity. Livest Sci 101:150-158.

Fu Y and Li W (1993) Statistical tests of neutrality of mutations. Genetics 133:693-709.

Guo SW and Thompson EA (1992) Performing the exact test of Hardy-Weinberg proportion for multiple alleles. Biometrics 48:361-372.

Hasui Y, Ponçano WL, Bistrichi CA, Stein DP, Galvão CACF, Gimenez AF, Almeida MA, Pires Neto AG, Melo MS and Santos MCSR (1978) Geologia da Região Administrativa 3 (Vale do Paraíba) e parte da Região Administrativa 2 (Litoral) do Estado de São Paulo. Instituto de Pesquisas Tecnológicas, São Paulo, 78 p.

Hiruma S, Riccomini C and Modenesi-Gauttieri MC (2001) Neotectônica no planalto de Campos do Jordão, SP. Rev Bras Geocienc 31:375-384.

Hurlbert SH (1971) The nonconcept of species diversity: A critique and alternative parameters. Ecology 52:577-586.

Ingenito LFS and Buckup PA (2007) The Serra da Mantiqueira, south-eastern Brazil, as a biogeographical barrier for fishes. J Biogeogr 34:1173-1182.

Jonsson B and Jonsson N (1993) Partial migration: Niche shift versus sexual maturation in fishes. Rev Fish Biol Fisher 3:348-365.

Kalinowski ST (2005) HP-RARE 1.0: A computer program for performing rarefaction on measures of allelic richness. Mol Ecol Notes 5:187-189.

Kumar S, Stecher G and Tamura K (2016) MEGA7: Molecular Evolutionary Genetics Analysis Version 7.0 for bigger datasets. Mol Biol Evol 33:1870-1874.

Limeira DM, Santos MH, Mateus RP, Almeida MC and Artoni RF (2019) Genetic variability in a population of Astyanax scabripinnis: Recent bottleneck and the possible influence of individuals with B chromosomes. Acta Sci - Biol Sci 41:e47323.

Matschiner M and Salzburger W (2009) Tandem: Integrating automated allele binning into genetics and genomics workflows. Bioinformatics 25:1982-1983.

Modenesi-Gauttieri MC and Hiruma ST (2004) A expansão urbana no planalto de Campos do Jordão. Diagnóstico geomorfológico para fins de planejamento. Rev Inst Geol 25:1-28.

Modenesi-Gauttieri MC, Hiruma TS and Riccomini C (2002) Morphotectonics of a high plateau on the Northwestern flank of the continental rift of Southeastern Brazil. Geomorphology 43:257-271.

Moreira-Filho O and Bertollo LCA (1991) Astyanax scabripinnis (Pisces, Characidae): A species complex. Braz J Genet 14:331357.

Moreira-Filho O, Galetti PM and Bertollo LAC (2004) B chromosomes in the fish Astyanax scabripinnis (Characidae, Tetragonopterinae): An overview in natural populations. Cytogenet Genome Res 106:230-234.
Nei M (1987) Molecular Evolutionary Genetics. Columbia University Press, New York. 512 p.

Néo DM, Moreira-Filho O and Camacho JPM (2000) Altitudinal variation for B chromosome frequency in the characid fish Astyanax scabripinnis. Heredity (Edinb) 85:136-141.

Ornelas-Garcia CP, Dominguez-Dominguez O and Doadrio I (2008) Evolutionary history of the fish genus Astyanax Baird \& Girard (1854) (Actinopterygii, Characidae) in Mesoamerica reveals multiple morphological homoplasies. BMC Evol Biol 8:340.

Panaram K and Borowsky R (2005) Gene flow and genetic variability in cave and surface populations of the Mexican Tetra, Astyanax mexicanus (Teleostei: Characidae). Copeia 2:409-416.

Peakall R and Smouse PE (2012) GenAlEx 6.5: Genetic analysis in Excel. Population genetic software for teaching and researchan update. Bioinformatics 28:2537-2539.

Pritchard JK, Stephens M and Donnelly P (2000) Inference of population structure using multilocus genotype data. Genetics 155:945-959.

Protas ME, Hersey C, Kochanek D, Zhou Y, Wilkens H, Jeffery WR, Zon LI, Borowsky R and Tabin CJ (2006) Genetic analysis of cavefish reveals molecular convergence in the evolution of albinism. Nat Genet 38:107-111.

Raymond M and Rousset F (1995) GENEPOP (version 1.2): Population genetics software for exact tests and ecumenicism. J Hered 86:248-249.

Rice WR (1989) Analyzing tables of statistical tests. Evolution 43:223-225.

Schuelke M (2000) An economic method for the fluorescent labeling of PCR fragments. Nat Biotechnol 18:233-234.

Sivasundar A, Bermingham E and Ortí G (2001) Population structure and biogeography of migratory freshwater fishes (Prochilodus: Characiformes) in major South American rivers. Mol Ecol 10:407-417.

Souza IL and Moreira-Filho O (1995) Cytogenetic diversity in the Astyanax scabripinnis species complex (Pisces, Characidae). I. Allopatric distribution in a small stream. Cytologia 60:1-11.

Spencer CC, Neigel JE and Leberg PL (2000) Experimental evaluation of the usefulness of microsatellite DNA for detecting demographic bottlenecks. Mol Ecol 9:1517-1528.

Strecker U, Bernatchez L and Wilkens H (2003) Genetic divergence between cave and surface populations of Astyanax in Mexico (Characidae, Teleostei). Mol Ecol 12:699-710.

Tajima F (1989) Statistical method for testing the neutral mutation hypothesis by DNA polymorphism. Genetics 123:585-595.

Terán GE, Benitez MF and Mirande JM (2020) Opening the Trojan horse: Phylogeny of Astyanax, two new genera and resurrection of Psalidodon (Teleostei:Characidae). Zool J Linn Soc-Lond 190:1217-1234.

Triantafyllidis A, Leonardos I, Bista I, Triantafyllidis A, Leonardos I, Bista I, Kyriazis ID, Stoumboudi MTH, Kappas I, Amat F et al. (2007) Phylogeography and genetic structure of the Mediterranean killifish Aphanius fasciatus (Cyprinodontidae). Mar Biol 152:1159-1167.

Van Oosterhout C, Hutchinson WF, Wills DPM and Shipley P (2004) MICRO-CHECKER: Software for identifying and correcting genotyping errors in microsatellite data. Mol Ecol Notes 4:535-538.

Vera M, Sourinejad I, Bouza C, Vilas R, Pino-Querido A, Kalbassi MR and Martínez P (2010) Phylogeography, genetic structure, and conservation of the endangered Caspian brown trout, Salmo trutta caspius (Kessler, 1877), from Iran. Hydrobiologia 664:51-67.

Ward RD, Zemlak TS, Innes BH, Last PR and Hebert PDN (2005) DNA barcoding Australia's fish species. Philos Trans R Soc Lond B Biol Sci 360:1847-1857. 
Yue GH, David L and Orban L (2007) Mutation rate and pattern of microsatellites in common carp (Cyprinus carpio L.). Genetica 129:329-331.

Zaganini RL, Hashimoto DT, Pereira LHG, Oliveira C, Mendonça FF, Foresti F and Porto-Foresti F (2012) Isolation and characterization of microsatellite loci in the Neotropical fish Astyanax altiparanae (Teleostei: Characiformes) and crossspecies amplification. J Genet 91:e24-7.

\section{Internet Resources}

Structure Harvester (2012) http://taylor0.biology.ucla.edu/ structureHarvester/ (accessed 22 January 2021).

\section{Supplementary material}

Table S1 - Microsatellites annealing temperatures used in gradient test, repeat motifs and alleles length used in population study of six Psalidodon scabripinnis populations from the Serra da Mantiqueira region.

Associate Editor: Vera Maria Fonseca de Almeida e Val

License information: This is an open-access article distributed under the terms of the Creative Commons Attribution License (type CC-BY), which permits unrestricted use, distribution and reproduction in any medium, provided the original article is properly cited. 